\title{
The observed decline of Western Toads (Anaxyrus boreas) over several decades at a novel winter breeding site
}

\author{
BRIAN G. SLOUGH ${ }^{1, ~ *}$ and ALEXANDER DEBRUYN ${ }^{2}$ \\ 137-71 Aksala Drive, Whitehorse, Yukon Y1A 0M5 Canada \\ ${ }^{2}$ Department of Zoology, University of British Columbia, 4200-6270 University Boulevard, Vancouver, British Columbia \\ V6T 1 Z4 Canada \\ *Corresponding author: slough@northwestel.net
}

Slough, B.G., and A. deBruyn. 2018. The observed decline of Western Toads (Anaxyrus boreas) over several decades at a novel winter breeding site. Canadian Field-Naturalist 132(1): 53-57. https://doi.org/10.22621/cfn.v132i1.2026

\begin{abstract}
The Western Toad (Anaxyrus boreas) population of the Atlin Warm Springs in northwestern British Columbia has persisted since at least 1924. An extraordinary feature of the population has been winter breeding in late February to early March, while nearby cold-water populations breed in late-May. Metamorphosis of tadpoles, enhanced by the warm water, occurs as early as late-March. In 2008, Amphibian Chytrid Fungus (Batrachochytrium dendrobatidis) was documented in toadlets at the warm springs. Until 2005 , as many as eight egg clutches and 25 breeding adults had been observed at the warm springs, after which the population declined. In 2017, novel spring breeding occurred in a cooler pond in the spring complex. Future observations will help determine whether the population is recovering and whether breeding phenology and habitat use have changed.
\end{abstract}

Key words: Amphibian Chytrid Fungus; Anaxyrus boreas; Batrachochytrium dendrobatidis; breeding population; breeding habitat; northwestern British Columbia; Western Toad; warm springs

\section{Introduction}

Since at least 1924, the Western Toad (Anaxyrus boreas) population of the Atlin Warm Springs has received substantial attention from biologists and naturalists, inspired by the relatively dense population that bred in a small and discrete habitat near the town of Atlin, British Columbia. The population occurs at the most northerly latitude of the species' range (Matsuda et al. 2006; Slough and Mennell 2006; Slough 2013). Cook (1977) collated some of the records of Western Toads from Yukon and northern British Columbia, and Slough (2009) summarized additional observations and specimens collected from 1924 to 2009. Additional observations to 2012 were contributed by B.G.S. to the COSEWIC assessment and status report on the Western Toad, Non-calling population (COSEWIC 2012). An unusual feature of the warm springs population was that breeding occurred in late February through early March, while adjacent cold-water populations congregated to breed in a 2-week period from late May through early June after ice breakup (Slough and Mennell 2006).

Local residents of Atlin and Whitehorse have traditionally observed toadlets at the springs over the Easter holidays (i.e., shortly after the vernal equinox on 21 March). Early breeding, in late March, has also been reported for Western Toad populations at warm springs in Utah (Thompson 2004). Some toads in Utah did not hibernate and were active year-round. It is not known whether the toads of the Atlin Warm Springs hibernate or remain active in winter.

\section{Methods}

The Atlin Warm Springs is a cluster of geothermal springs that arise near Warm Bay on the east side of Atlin Lake in northwestern British Columbia $\left(59.404^{\circ} \mathrm{N}\right.$, $\left.133.575^{\circ} \mathrm{W}\right), 20 \mathrm{~km}$ south by southwest of the town of Atlin, and about $650 \mathrm{~m}$ from the lake (Figure 1). A second set of springs is located about $300 \mathrm{~m}$ to the west, and both drain into Atlin Lake. There are several underground sources of spring water, although most of the water emerges in three primary source pools. The largest source pool ( $\leq 10 \mathrm{~m}$ in diameter and $1 \mathrm{~m}$ deep $)$ and several smaller pools $(<0.5 \mathrm{~m}$ in depth), drain into a common stream. The largest pool was mechanically excavated for bathing.

The water is clear and odourless. Water temperature is $29^{\circ} \mathrm{C}$ at the large source pool, with pool and drainage stream temperatures $23-27^{\circ} \mathrm{C}$ at breeding sites in March and up to $29^{\circ} \mathrm{C}$ in summer. A single cooler spring-fed pond $\left(15^{\circ} \mathrm{C}\right.$ in winter) lies at a slightly lower elevation in the centre of the warm springs complex (spring 2017 breeding site in Figure 1). Shallow tufa (calcite) basins are present where the stream cascades downslope and runs underground for about $30 \mathrm{~m}$. The tufa deposits are porous and may provide hibernacula, hiding places, and foraging habitat for Western Toads.

Annual growth of vegetation in the springs begins in March. Vegetation consists of green algae, Small Duckweed (Lemna minor L.) and introduced Small-leaved Watercress (Nasturtium microphyllum Boenninghausen ex Reichenbach). Lake Chub (Couesius plumbeus) in-

A contribution towards the cost of this publication has been provided by the Thomas Manning Memorial Fund of the Ottawa Field-Naturalists' Club. 


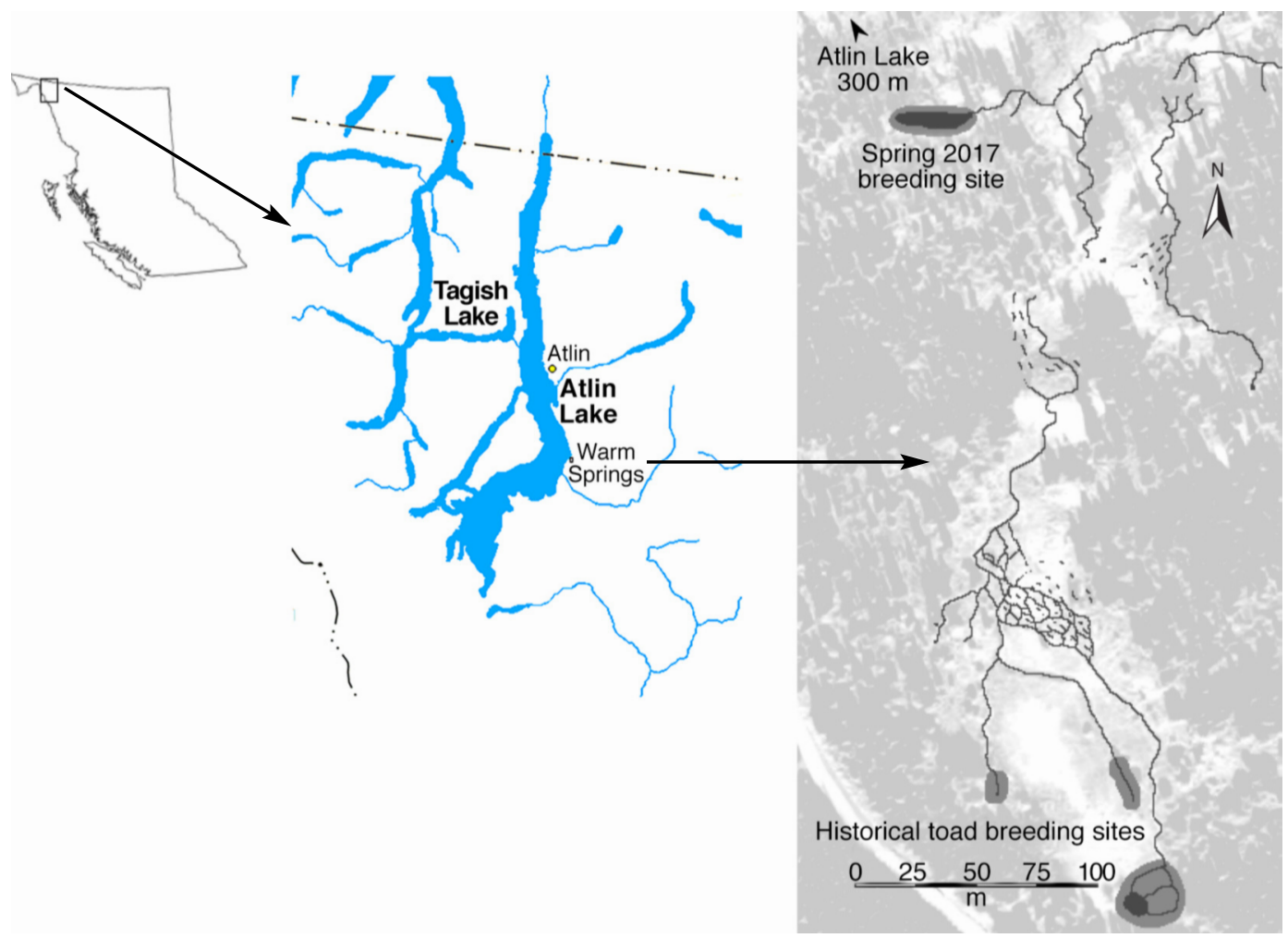

FigURE 1. Atlin Warm Springs complex, northwestern British Columbia $\left(59.404^{\circ} \mathrm{N}, 133.575^{\circ} \mathrm{W}\right)$, showing historical winter and 2017 spring breeding sites (grey shading). Breaks in streams indicate underground flow. Forest and meadows shown in background of spring complex with Imagery (C2018 DigitalGlobe, map data (C2018 Google.

habit the springs. We have observed Red Marshworm (Lumbricus rubellus), a potential prey of the Western Toad, to be abundant in the meadows surrounding the springs. Goldfish (Carassius auratus) were introduced to the western springs in about 2000 (S. Badhwar pers. comm. 11 March 2007), and Red Cherry Shrimp (Neocaridina davidi) were introduced to the eastern springs between October and December 2015 (A.dB. pers. obs.). Lake Chub and Red Cherry Shrimp are absent from the cooler pond.

Between 1996 and 2018, we searched for Western Toads in the Atlin Warm Springs using visual encounter surveys of the source springs, streams, and surrounding meadows (Table 1). The breeding sites and meadows encompassed about 1 ha and were surveyed in $1-2 \mathrm{~h}$. Adults were rarely found far from water or outside of the breeding season. They may have dispersed from the site to other summer foraging habitats, or they may have gone underground into crevices created by the tufa. We also solicited observations from Environment Yukon and Environment Canada based out of Whitehorse. In addition, observations were made by A.dB. during a study of Lake Chub and Cherry Shrimp in 2017.

\section{Results}

Numerous observations of Western Toads at the Atlin Warm Springs from 1924 through 2005 indicate that a healthy breeding population persisted for at least 80 years (Table 1). After 2005, breeding activity and sightings of adults became sporadic, suggesting a population decline. Amphibian Chytrid Fungus (Batrachochytrium dendrobatidis $[B d]$ ) was detected on Western Toad juveniles and adults from adjacent Atlin Lake in 2007 and on toadlets from the warm springs in 2008 (Slough 2009). Since 2005, observations have consisted of two clutches of eggs in 2008, one toadlet and one adult in 2012 , and one toadlet in 2014. There has been no other evidence of breeding at the historical breeding sites within the springs in other years between 2006 and 2018. Three dead adult Western Toads were found in or near the springs on 7 March 2005, where at least four aggregations of recently hatched tadpoles were present. There was no obvious trauma to the dead toads.

Breeding behaviour, involving $\geq 25$ adults and $\geq 8$ egg clutches, was observed between 7 and 22 March in five years between 1998 and 2005 (Figure 2). Records of newly hatched larvae suggest that oviposition occurred during or before 4-10 March. Larvae that were 
TABLE 1. Western Toad (Anaxyrus boreas) observations at the Atlin Warm Springs, northwestern British Columbia ( $59.404^{\circ} \mathrm{N}$, $\left.133.575^{\circ} \mathrm{W}\right), 1996-2018$. Larval stages after Gosner (1960). Absence of data for some years indicate that the site was not visited.

\begin{tabular}{|c|c|c|c|}
\hline Date & Eggs & Tadpoles & Terrestrial stages \\
\hline Early April 1996 & 0 & Numerous & 0 \\
\hline 22 March 1998 & 0 & $\begin{array}{l}\text { Wide range of stages } \\
(26-45) \text {, from early } \\
\text { to near metamorphosis }\end{array}$ & 0 \\
\hline 12 February 1999 & 0 & 0 & 0 \\
\hline 13 March 1999 & $\geq 8$ clutches & Newly hatched (stage 20) & $\begin{array}{l}1 \text { dead yearling; } \geq 6 \text { adults, } \\
\text { including } 4 \text { calling males and } \\
\text { spawned female }\end{array}$ \\
\hline 9 March 2001 & 0 & $\begin{array}{l}\text { Early to mid-stages } \\
(20-30+)\end{array}$ & $\geq 25$ breeding in 4 areas \\
\hline 7 March 2005 & 0 & $\begin{array}{l}\geq 4 \text { recently hatched } \\
\text { aggregations (stage } 26+\text { ) }\end{array}$ & $\begin{array}{l}1 \text { male and } 3 \text { dead adults } \\
\text { ( } 1 \text { frozen on land, } 2 \text { in stream) }\end{array}$ \\
\hline 21 March 2005 & 0 & To stage 40 & 0 \\
\hline 21 March, 3 June 2006 & 0 & 0 & 0 \\
\hline 12 March, 19 April 2007 & 0 & 0 & 0 \\
\hline 10 March 2008 & 0 & $\begin{array}{l}\sim 500 \text { tadpoles (stages } 26-30 \text { ). } \\
\text { Estimated: } 2 \text { clutches }\end{array}$ & 0 \\
\hline 10 May 2008 & 0 & 0 & 100s metamorphs (stages 44-46) \\
\hline 27 April 2009 & 0 & 0 & 0 \\
\hline 6 April 2010 & 0 & 0 & 0 \\
\hline 15 March, 2 July 2011 & 0 & 0 & 0 \\
\hline 12 August 2012 & 0 & 0 & $\begin{array}{l}1 \text { adult, } 1 \text { toadlet } \\
\text { (S. Stotyn, S. Cannings) }\end{array}$ \\
\hline 18 March 2013 & 0 & 0 & 0 \\
\hline 28 June 2014 & 0 & 0 & 1 toadlet (S. Stotyn, S. Cannings) \\
\hline 20 June 2016 & 0 & 0 & 0 (S. Stotyn, S. Cannings) \\
\hline 16 May 2017 & 0 & 0 & 0 (J. Hobbs) \\
\hline 17 June 2017 & 0 & $\begin{array}{l}3 \text { aggregations, possibly from } \\
\text { one egg clutch, downstream } \\
\text { from traditional breeding sites }\end{array}$ & 2 adults (A.dB., E. Titley) \\
\hline $\begin{array}{l}25 \text { February, } 31 \text { March, } \\
27 \text { May } 2018\end{array}$ & 0 & 0 & 0 (B.G.S., A.dB.) \\
\hline
\end{tabular}

Sources: Observations by B.G.S. unless noted. Presence/absence data to 2012 were previously presented by Slough (2009) and COSEWIC (2012).

near metamorphosis (stage 45; Gosner 1960) observed on 22 March 1998 placed oviposition in mid-February using developmental times of Olson (2005). However, development may be more rapid in the warm water of the springs compared with cold-water habitats, as egg and tadpole development are largely temperature dependent (Matsuda et al. 2006). Western Toad eggs reportedly hatch within 3-12 days (Olson 2005) or 7-10 days (Matsuda et al. 2006) across the species' range. Goettl (unpubl. data 1996 as cited in Loeffler 2001) reported Western Toad eggs hatching in 5-7 days at $19^{\circ} \mathrm{C}$ with completion of metamorphosis 45 days post-breeding in the Southern Rocky Mountain population. Maxell et al. (2002) have reported time to hatching of $\leq 7$ days in Montana, with metamorphosis $\leq 42$ 49 days post-oviposition. Metamorphosis may take up to three months in some systems (Olson 2005).

At least three clusters of tadpoles (possibly from one egg clutch) were observed at the only cooler pond within the Atlin Warm Springs complex on 17 June 2017, long after the late March to early April metamorphosis, which follows winter breeding (Figure 2). The tadpoles were not handled on site, but, from photographs, they appear to be at Gosner stage $\geq 30$, indicating breeding in late May, as is typical for regional cold-water populations. Two adults were observed in terrestrial meadow habitat adjacent to the historical warm springs breeding habitat.

\section{Discussion}

Batrachochytrium dendrobatidis must be considered a factor contributing to the local population decline of Western Toads observed from 2006 to 2018 . The fungus causes the infectious disease chytridiomycosis, a global threat to Western Toads across the range of the species (summarized in COSEWIC 2012). Water temperatures in the warm springs (average of $26^{\circ} \mathrm{C}$ in winter) are near the thermal maximum for $B d$ growth (26$28^{\circ} \mathrm{C}$; Stevenson et al. 2013); however, the thermal tolerance of $B d$ strains is variable and the fungus is known to be adaptable to temperature conditions (Voyles et al. 2017). A temperate strain of $B d$ from 

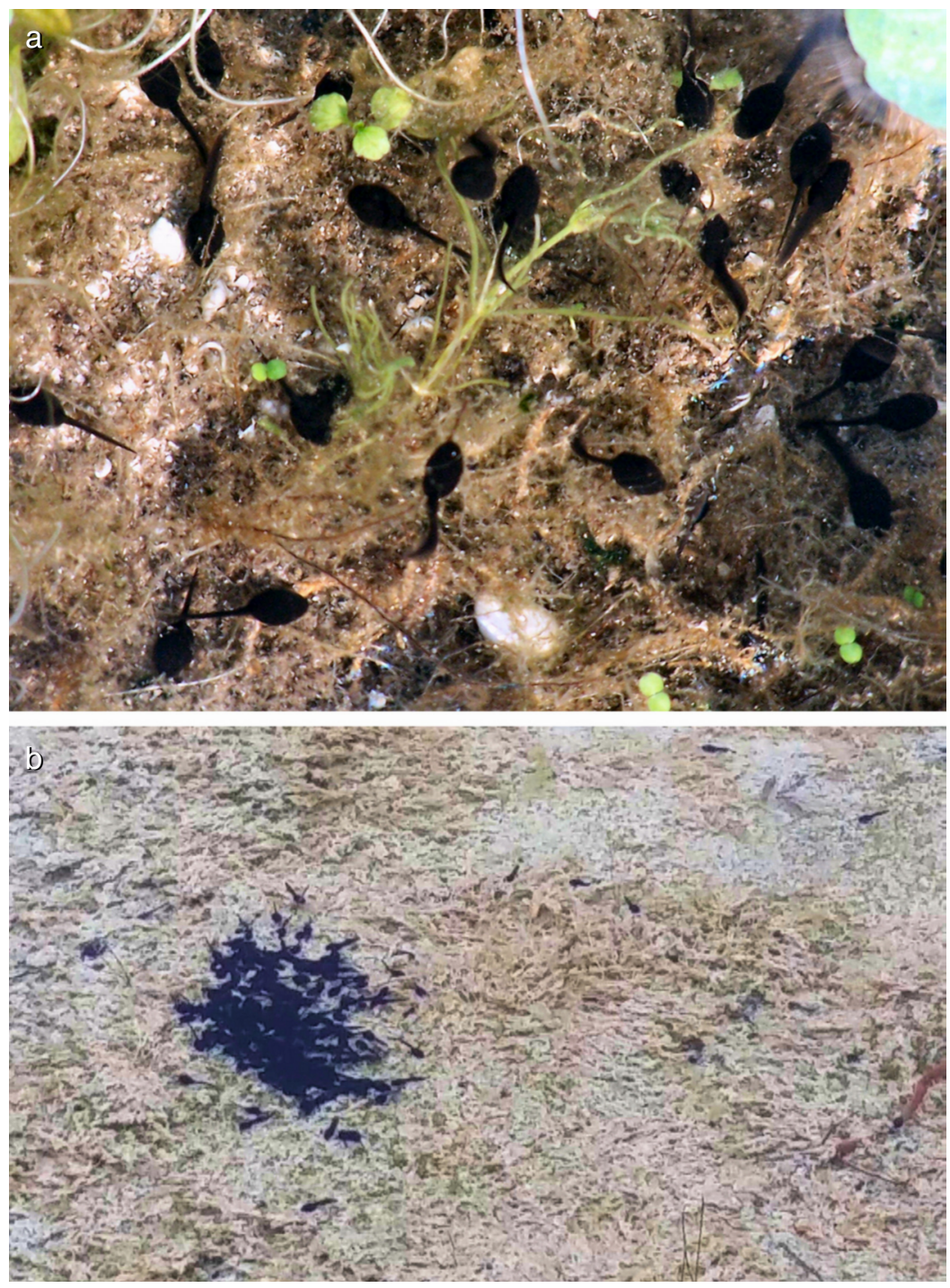

Figure 2. Western Toad (Anaxyrus boreas) tadpoles in the Atlin Warm Springs, northwestern British Columbia $\left(59.404^{\circ} \mathrm{N}\right.$, 133.575 W), on 7 March 2005 (a) and 17 June 2017 (b). Photos: B. Slough (a) and A. deBruyn (b).

California grew well at $2-27^{\circ} \mathrm{C}$ and following freeze and heat shock treatments (Voyles et al. 2017). The Atlin Warm Springs are not likely a refuge from $B d$.

The recovery of the Western Toad population of the Atlin Warm Springs may be limited by life cycle and reproduction. Females mature at 4-6 years of age, and most breed only once in their lifetime (summarized in COSEWIC 2012).

Climate change and severe weather are expected to have a low impact on Western Toad populations in British Columbia (Environment and Climate Change Canada 2016), although the predicted increase and frequency of droughts may threaten small wetland breeding sites and micro-sites used for rehydration (Provincial Western Toad Working Group 2011). Climate warming is expected to affect the phenology of breeding, larval development, and hibernation. In 2005, a single stochastic cold weather event during breeding did not appear to be the cause of mortalities and the subsequent population decline. In fact, March 2005 was relatively mild: daily mean $-1.1^{\circ} \mathrm{C}$, versus a long-term mean of $-5.5^{\circ} \mathrm{C}$ for 1981 to 2010 (Environment and Climate Change Canada 2018; data from Atlin, British Columbia weather station, $20 \mathrm{~km}$ north-northwest of the Atlin Warm Springs). Nonetheless, activity during freezing temperatures, such as movements from hibernacula to breeding sites, places Western Toad at risk of exposure.

Amphibians including Western Toads are known to exhibit adaptive responses to climate change, such as 
adjusting breeding phenology in response to warmer temperatures (Blaustein et al. 2001; Urban et al. 2014). Other plastic responses include enlarged clutch size, more rapid growth and development rate, and increased survival. This plasticity is possibly shared by the Atlin Warm Springs population of Western Toads.

We can only speculate on the cause of the novel spring and cool-water breeding observed in 2017. Was the warm springs Western Toad population extirpated and re-colonized by individuals with cold-water breeding patterns and habitat preference, or did surviving toads switch phenology and habitat in response to unknown factors in the warm springs? Western Toad tadpoles were observed at four sites on Atlin Lake in 2017 (Hobbs 2018), where the population appears healthy. The aggregating behaviour of cold-water tadpoles along shallow shorelines, where the water is sun-warmed, has not been observed at the warm springs.

\section{Acknowledgements}

We thank the people who contributed observations or assisted us with field surveys, including Shannon Stotyn and Syd Cannings, Canadian Wildlife Service, Environment and Climate Change Canada, Whitehorse, Yukon; Heather Milligan, Environment Yukon, Whitehorse, Yukon; and Jared Hobbs, Hemmera Envirochem Inc., Victoria, British Columbia. Laura Friis and Stephen Leaver, Ecosystems Branch, BC Ministry of Environment, Victoria, British Columbia, provided financial and field support to B.G.S. in 2007. Local homesteader, Stephen Badhwar, who lives at the western springs, provided the year for the Goldfish introduction. Financial support for A.dB. was provided by the Association of Canadian Universities for Northern Studies and the University of British Columbia Department of Zoology. Field support for A.dB. was provided by Eric Titley and Gordon de Bruyn.

\section{Literature Cited}

Blaustein, A.R., L.K. Belden, D.H. Olson, D.M. Green, T.L. Root, and J.M. Kiesecker. 2001. Amphibian breeding and climate change. Conservation Biology 15: 18041809. https//doi.org/10.1046/j.1523-1739.2001.00307.x

Cook, F.R. 1977. Records of the boreal toad from the Yukon and northern British Columbia. Canadian Field-Naturalist 91: 185-186. Accessed 30 June 2018. https://biodiversity library.org/page/28061392.

COSEWIC (Committee on the Status of Endangered Wildlife in Canada). 2012. COSEWIC assessment and status report on the Western Toad Anaxyrus boreas in Canada. COSEWIC, Ottawa, Ontario, Canada. Accessed 21 May 2018. https://www.registrelep-sararegistry.gc.ca/virtual_sara /files/cosewic/sr_Western Toad_2013_e.pdf.

Environment and Climate Change Canada. 2016. Management plan for the Western Toad (Anaxyrus boreas) in Canada [proposed]. Species at Risk Act Management Plan Series. Environment and Climate Change Canada, Ottawa, Ontario, Canada. Accessed 5 July 2018. http://www.regist relep-sararegistry.gc.ca/virtual_sara/files/plans/mp-westerntoad-e-proposed.pdf.

Environment and Climate Change Canada. 2018. Canadian climate normals: 1981-2010 climate normals and aver- ages. Environment and Climate Change Canada, Ottawa, Ontario, Canada. Accessed 31 January 2018. http://climate. weather.gc.ca/climate_normals/index_e.html.

Gosner, K.L. 1960. A simplified table for staging anuran embryos and larvae with notes on identification. Herpetologica 16: $183-190$.

Hobbs, J. 2018. Taku River Tlingit First Nation environmental DNA assessment for western toad. Environment and Climate Change Canada Project ID-2017AFSAR2969. Prepared for Taku River Tlingit First Nation, Atlin, British Columbia, by Hemmera Envirochem Inc., Victoria, British Columbia, Canada.

Loeffler, C. 2001. Conservation plan and agreement for the management and recovery of the southern Rocky Mountain population of the boreal toad (Bufo boreas boreas). Boreal Toad Recovery Team, Colorado Division of Wildlife, Species Conservation Section, Denver, Colorado, USA.

Matsuda, B.M., D.M. Green, and P.T. Gregory. 2006. Amphibians and Reptiles of British Columbia. Royal BC Museum Handbook. Royal BC Museum, Victoria, British Columbia, Canada.

Maxell, B.A., K.J. Nelson, and S. Browder. 2002. Record clutch size and observations on breeding and development of the Western Toad (Bufo boreas) in Montana. Northwestern Naturalist 83: 27-30. https://doi.org/10.2307/3536513

Olson, D.H. 2005. Western toad. Pages 162-165 in Amphibians of the Pacific Northwest. Edited by L.L.C. Jones, W.P. Leonard, and D.H. Olson. Audubon Society, Seattle, Washington, USA.

Provincial Western Toad Working Group. 2014. Management Plan for the Western Toad (Anaxyrus boreas) in British Columbia. Prepared for the B.C. Ministry of Environment, Victoria, British Columbia, Canada.

Slough, B.G. 2009. Amphibian chytrid fungus in western toads (Anaxyrus boreas) in British Columbia and Yukon, Canada. Herpetological Review 40: 319-321.

Slough, B.G. 2013. Occurrence of amphibians in British Columbia north of $57^{\circ} \mathrm{N}$. Northwestern Naturalist 94: 180-186. https://doi.org/10.1898/12-37.1

Slough, B.G., and R.L. Mennell. 2006. Diversity and range of amphibians of the Yukon Territory. Canadian FieldNaturalist 120: 87-92. https://doi.org/10.22621/cfn.v120i1. 251

Stevenson, L.A., R.A. Alford, S.C. Bell, E.A. Roznik, L. Berger, and D.A. Pike. 2013. Variation in thermal performance of a widespread pathogen, the amphibian chytrid fungus Batrachochytrium dendrobatidis. PLoS ONE 8(9): e73830. https://doi.org/10.1371/journal.pone.0073830

Thompson, P.D. 2004. Observations of boreal toad (Bufo boreas) breeding populations in northwestern Utah. Herpetological Review 35: 342-344.

Urban, M.C., J.L. Richardson, and N.A. Freidenfelds. 2014. Plasticity and genetic adaptation mediate amphibian and reptile responses to climate change. Evolutionary Applications 7: 88-103. https://doi.org/10.1111/eva.12114

Voyles, J., L.R. Johnson, J. Rohr, R. Kelly, C. Barron, D. Miller, J. Minster, and E.B. Rosenblum. 2017. Diversity in growth patterns among strains of the lethal fungal pathogen Batrachochytrium dendrobatidis across extended thermal optima. Oecologia 184: 363-373. https://doi.org/10. 1007/s00442-017-3866-8

Received 28 December 2017

Accepted 9 March 2018 